\section{UJMM



Volume 4 | 2011 Fall

\section{Undergraduate Journal of Mathematical}

Modeling: One + Two

2011

\title{
Design of a Rainwater Catchment System
}

Neil Cammardella

University of South Florida

\author{
Advisors: \\ Richard Stark, Mathematics and Statistics \\ Scott Campbell, Chemical \& Biomedical Engineering \\ Problem Suggested By: Scott Campbell
}

Follow this and additional works at: https://digitalcommons.usf.edu/ujmm

Part of the Mathematics Commons

UJMM is an open access journal, free to authors and readers, and relies on your support: Donate Now

\section{Recommended Citation}

Cammardella, Neil (2011) "Design of a Rainwater Catchment System," Undergraduate Journal of Mathematical Modeling: One + Two: Vol. 4: Iss. 1, Article 6.

DOI: http://dx.doi.org/10.5038/2326-3652.4.1.6

Available at: https://digitalcommons.usf.edu/ujmm/vol4/iss1/6 


\title{
Design of a Rainwater Catchment System
}

\begin{abstract}
Certain dimensions of a rainwater catchment and storage system were optimized using climatological and sociological data. Using only daily demand and average daily rain fall data, the following dimensions were optimized: 1) The horizontal roof area needed to collect the daily demand of water, 2) The tank size needed to store all the water collected during a heavy rain event, 3) When full, how long the tank will be able to provide water without rain, and 4) The diameter of the outlet flow orifice. With these calculations, we can design a rainwater catchment system that can capture the daily demand and store excess water for use during periods of low rain.
\end{abstract}

\section{Keywords}

Environmental Conservation, Water Supply, Rainfall

Creative Commons License

(c) (i) (3)

This work is licensed under a Creative Commons Attribution-Noncommercial-Share Alike 4.0 License. 


\section{TABLE OF CONTENTS}

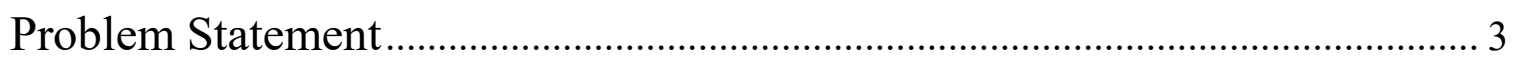

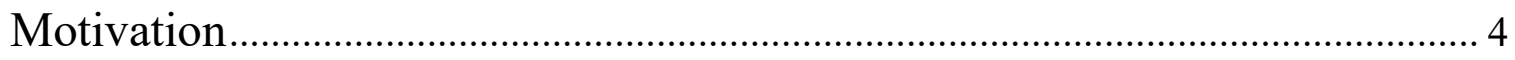

Mathematical Description and Solution Approach ............................................. 5

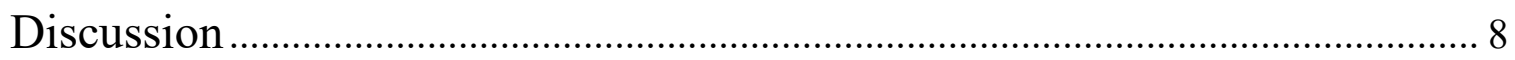

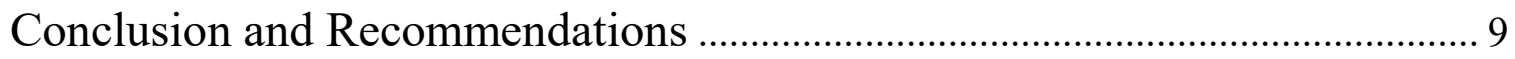

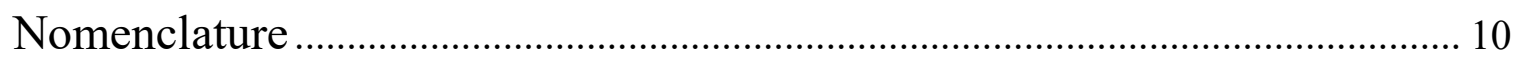

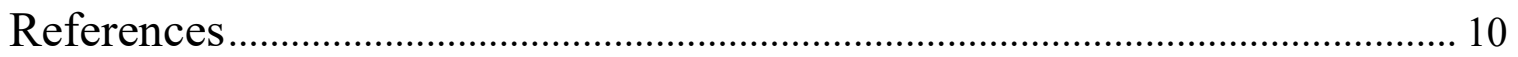




\section{PROBLEM STATEMENT}

We wish to design a rainwater catchment system for a particular daily water usage and rain rate.

I. Given an average daily rainfall, what horizontal roof area is be needed to collect the daily demand?

II. Now consider the storage tank. We would like the liquid height to be 1 meter just before a daily rain event. Suppose the roof area is the value calculated in part (a) based on an average rain event. We wish to design the tank to be able to collect all the rain on a day where more than the average falls. Suppose the maximum rain event is 1 inch $(0.0254$ $\mathrm{m}$ ) per day and that the tank is $3 \mathrm{~m}$ tall (it can't be taller because the roof is only slightly higher than $3 \mathrm{~m}$ ). What should the tank diameter, $D$, be in order to be able to store all the rain for the maximum rain event? Assuming no rainfall, for how many days will this tank still meet the daily demand?

III. A difficulty in determining the required orifice area at the tank exit is that the demand during the day is not constant. A different design criterion might be that, in an emergency, we would like to be able to drain the tank in a certain time. Suppose we desire that we are able to drain the tank from a height of $1 \mathrm{~m}$ in 6 hrs. What should the orifice diameter be? 


\section{MOTIVATION}

On October 31, 2011, the United Nations announced that world population had reached 7 billion (UN News Center). A growing population presents numerous challenges and opportunities. One such challenge is providing clean drinking water to every person. In 2010, 884 million people did not have access to improved drinking water (World Health Organization and UNICEF).

The USF chapter of Engineers Without Borders (EWB-USF) is committed to improving access to clean water for the residents of Miramar in the Dominican Republic. Miramar is a community of 500 people in the municipality of Miches, on the northeastern coast of the island. Other communities in the area are serviced by a gravity-powered system, but Miramar's height makes this impossible. Can a rainwater catchment system be designed to meet the needs of this community?

This global issue is also of local importance. Cynthia Barnett's book, Mirage, states that, "Officials in four of Florida's five water-management districts report that they do not have enough water to supply projected population growth past the year 2025." (Barnett) By augmenting or replacing the water provided by municipalities, rainwater catchment systems could help Floridians become more drought-resistant and less dependent on rapidly depleting groundwater.

The objective of this project is to calculate the dimensions of an effective rainwater catchment system using climatological and sociological data. In order for a rainwater catchment system to be effective, the roof area should be large enough to capture the water needed to meet the daily demand and the tank should be able to store enough water to last through periods with 
low rainfall. A simple way to provide water during periods of low rainfall is to build the tank large enough to store the excess water during periods of heavy rain.

\section{MATHEMATICAL DESCRIPTION AND SOLUTION APPROACH}

According to a Post-Trip Assessment Report filed by EWB-USF from March, 2009, the community of Miramar will need to be supplied with 10,000 gallons of water per day. During the summer of 2012, EWB-USF intends to build a pilot rainwater catchment system. A consumption rate of 3.78 cubic meters (1,000 gallons) per day will be used in this report. Rainfall data for Miramar could not be found, so data from Punta Cana, a city 70 miles to the southeast, will be used. Average daily rainfall in Punta Cana is $0.00279 \mathrm{~m}$ (0.11 in) per day.

\section{AREA OF ROOF}

The horizontal roof area $\left(A_{h f}\right)$ can be calculated by dividing the daily demand $\left(V_{d d}\right)$ by the average daily rainfall $\left(H_{\text {adr }}\right)$.

$$
A_{h f}=\frac{V_{d d}}{H_{a d r}}=\frac{3.78}{.00279}=1,354.84 \mathrm{~m}^{2}
$$

Thus the horizontal roof area must be at least $1,354.84 \mathrm{~m}^{2}$ to capture the daily demand of water.

\section{COLLECTION TANK DIAMETER}

The 3 meter tall, cylindrical, storage tank must be large enough to store all the water produced during a heavy rain event, supposing the tank is already $1 \mathrm{~m}$ full. The amount of rain produced in a heavy rain event $\left(H_{\max }\right)$ was chosen to be $0.0254 \mathrm{~m}(1 \mathrm{in})$. The volume of rain captured by the system $\left(V_{\max }\right)$ is calculated by multiplying the horizontal roof area by the height of rain. 


$$
V_{\text {max }}=A_{h f} \times H_{\text {max }}
$$

In order to calculate the diameter of our tank $\left(D_{t}\right)$, we set $V_{\max }$ equal to the volume of a cylinder with height $2 \mathrm{~m}$ (the tank is $1 \mathrm{~m}$ full to begin). Therefore we have:

$$
V_{\max }=\pi\left(\frac{D_{t}}{2}\right)^{2}
$$

Now we manipulate equation (2) to reveal,

$$
D_{t}=\sqrt{2 A_{h f} \times \frac{H_{\max }}{\pi}}=4.681 \mathrm{~m}
$$

The tank must have a diameter of at least $4.681 \mathrm{~m}$ in order to store all the rain water captured in a once per year maximum rain event, assuming the tank is already $1 \mathrm{~m}$ full before the storm.

The amount of time, without rain, this full tank can provide water can be found by dividing the volume of our tank with the daily demand.

$$
\frac{V_{\text {tank }}}{V_{d d}}=\frac{51.628}{3.78}=13.66 \text { days }
$$

Hence, the tank can provide water for at least 13 days without rainfall.

The cylindrical storage tank shown below (Figure 1) is used to collect rain runoff from a roof and store the water for use.

- $Q_{\text {in }}$ represents the inlet flow rate to the tank (due to rain runoff) in $\mathrm{m}^{3} / \mathrm{hr}$

- $Q_{\text {out }}$ represents the outlet flow (for use) in $\mathrm{m}^{3} / \mathrm{hr}$. 


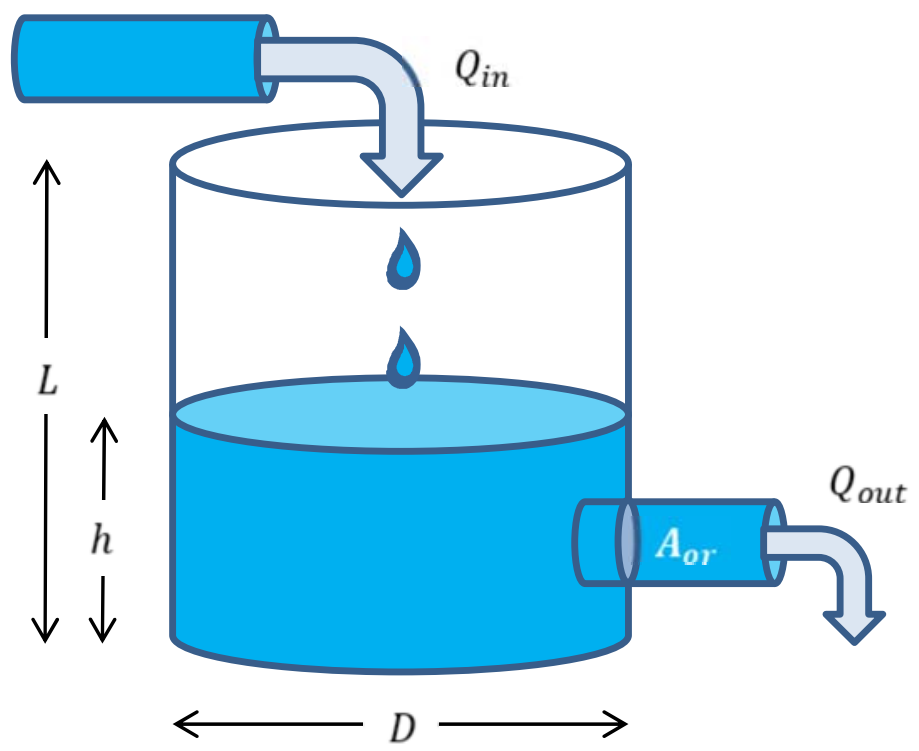

Figure 1: Diagram of the cylindrical rainwater catchment system.

The flow rate out of the tank is given by a modification of Torricelli's equation:

$$
Q_{\text {out }}=A_{\text {or }} C_{\text {dis }} \sqrt{2 g h}
$$

where:

- $A_{o r}$ is the orifice area (in $\left.\mathrm{m}^{2}\right)$,

- $\quad h$ is the liquid,

- level height,

- $C_{\text {dis }}$ is the discharge coefficient $\left(C_{\text {dis }}=.6\right)$, and

- $g$ is the gravitational constant $\left(g=9.8 \mathrm{~m} / \mathrm{s}^{2}\right)$.

The dynamics of the tank are obtained from a mass balance of water. This results in:

$$
\frac{\pi D^{2}}{4} \frac{d h}{d t}=Q_{\text {in }}-Q_{\text {out }}
$$




\section{DRAINAGE TIME}

In case of an emergency, the outlet flow orifice must have an area $A_{\text {or }}$ large enough to allow the tank to drain from a height of $1 \mathrm{~m}$ in 6 hours. Inserting equation (6) into equation (7) and setting $Q_{\text {in }}=0$ (no water will be allowed to enter the tank) this expression can be found:

$$
\frac{d h}{d t}=-\frac{4 A_{o r} C_{d i s} \sqrt{2 g h}}{\pi D_{t}^{2}}
$$

To solve for $A_{\text {or }}$ we separate the variables in (8) and integrate:

$$
\begin{gathered}
\frac{d h}{\sqrt{h}}=-\frac{4 A_{o r} C_{d i s} \sqrt{2 g}}{\pi D_{t}^{2}} d t \\
\int_{1}^{0} \frac{d h}{\sqrt{h}}=-\frac{4 A_{o r} C_{d i s} \sqrt{2 g}}{\pi D_{t}^{2}} \int_{0}^{21,600} d t \\
{[2 \sqrt{h}]_{1}^{0}=-\frac{4 A_{o r} C_{d i s} \sqrt{2 g}}{\pi D_{t}^{2}}[t]_{0}^{21,600}} \\
A_{o r}=\frac{\pi D_{t}^{2}}{43,200 C_{d i s} \sqrt{2 g}} .
\end{gathered}
$$

The diameter of this orifice $\left(D_{\text {or }}\right)$ can be calculated using:

$$
A_{o r}=\frac{\pi D_{o r}^{2}}{4}
$$

Finally (9) and (10) yield:

$$
D_{o r}=\sqrt{\frac{4.681^{2}}{10,800 \times 0.6 \times \sqrt{19.6}}}=27.7 \mathrm{~mm}(1.09 \mathrm{in}) .
$$

Thus, the diameter of the outlet flow orifice must be at least $27.7 \mathrm{~mm}$ to allow the tank to drain from a height of $1 \mathrm{~m}$ in 6 hours. 


\section{DISCUSSION}

The minimum horizontal roof area needed to supply Miramar with 3.78 cubic meters (1,000 gallons) of water per day is $1,354.84$ square meters. If this roof were on a square building, the sides would measure $36.81 \mathrm{~m}$ (120.8 ft).

The diameter of the tank was calculated to be $4.681 \mathrm{~m}(15.358 \mathrm{ft})$. A full tank of this size can provide our model community with water for at least 13 days.

If our tank needed to be drained in an emergency, an outlet flow orifice of diameter 27.7 $\mathrm{mm}(1.09 \mathrm{in})$ is large enough to drain the tank from a height of 1 meter in 6 hours

\section{CONCLUSION AND RECOMMENDATIONS}

Although Miramar needs 10,000 gallons of water per day, this proposed pilot system will only supply 1,000 gallons of water per day. The minimum horizontal roof area needed to supply Miramar with 3.78 cubic meters (1,000 gallons) of water per day is $1,354.84$ square meters $(14,583.4$ square feet). This may seem large at first glance, but consider this; if a structure supporting this roof were square, the sides would only need to measure $36.81 \mathrm{~m}$ (120.8 $\mathrm{ft}$ ). EWB-USF is already communicating with the community regarding possible public buildings to house the rainwater catchment system. If no public building is available, one can be erected that could serve another function as well. Miramar has no local school, so this is one possibility.

A tank of diameter $4.681 \mathrm{~m}(15.358 \mathrm{ft})$ and height of $3 \mathrm{~m}(9.84 \mathrm{ft})$ can provide 3.78 cubic meters (1,000 gallons) of water per day for at least 13 days. Since the tank is very large, it may be advisable to build multiple, smaller tanks. Also, if the pilot program is successful, EWB- 
USF will install a residential system in every home. When this happens, the tank size will be reduced dramatically.

Future research should be done regarding methods of rainwater treatment and the effect different roof materials have on rainwater quality. Also, proper maintenance of the system should be studied to ensure its longevity.

\section{NOMENCLATURE}

\begin{tabular}{|c|c|c|}
\hline Symbol & Description & Unit \\
\hline$A$ & Area & $m^{2}$ \\
\hline $\boldsymbol{V}$ & Volume & $m^{3}$ \\
\hline $\boldsymbol{h}$ & Height & $m$ \\
\hline$D$ & Diameter & $m$ \\
\hline$Q$ & Flow Rate & $\mathrm{m}^{3} / \mathrm{s}$ \\
\hline$C_{d i s}$ & Discharge Coefficient & - \\
\hline$g$ & Gravitational Constant & $\mathrm{m} / \mathrm{s}^{2}$ \\
\hline
\end{tabular}

\section{REFERENCES}

Barnett, Cynthia. Mirage. University of Michigan Press, 2007.

Larson, Ron, Robert Hostetler and Bruce Edwards. Calculus. 8th Edition. Boston, MA: Houghton Mifflin Company, 2005.

UN News Center. As World Passes 7 Billion Milestone, UN urges action to meet key challenges. 27 November 2011.

World Health Organization and UNICEF. Progress on Sanitation and Drinking Water:2010 Update. 27 November 2011. 